\title{
ANALISIS PENGENDALIAN INTERNAL PROSEDUR PENERIMAAN DAN PENGELUARAN PERSEDIAAN PADA PT. OSI ELECTRONICS BATAM
}

\section{ANALISYS OF THE INTERNAL CONTROL ACCEPTANCE PROCEDURE AND EXPENDING GOOD IN PT. OSI ELECTRONICS BATAM}

\author{
Yentina Siregar \\ Prodi Akuntansi, Fakultas Ekonomi, UNRIKA, Indonesia \\ Email: yentinasiregar@gmail.com
}

\begin{abstract}
Penelitian ini bersifat deskriptif kualitatif yang bertujuan untuk mengetahui prosedur dan pelaksanaan pengendalian internal prosedur penerimaan dan pengeluaran persediaan pada PT.OSI Electronics Batam. Penelitian ini menggunakan teknik purposive sampling dan jumlah informan adalah 10 narasumber.Teknik pengumpulan data yang digunakan adalah wawancara, dokumentasi, dan observasi. Hasil yang diperoleh dari penelitian ini adalah pelaksanaan pengendalian internal prosedur penerimaan dan pengeluaran persediaan sudah memadai karena sudah menjalankan indikator-indikator dari kelima aspek pengendalian internal, tetapi masalah-masalah yang muncul disebabkan oleh job rolling dalam waktu singkat, security pada penerimaan kurang memadai, kurangnya komunikasi antar anggota dan rangkap kerja pada clerk.
\end{abstract}

Kata Kunci :Pengendalian Internal, Prosedur Penerimaan Persediaan, Prosedur Pengeluaran Persediaan.

\begin{abstract}
Abstrak
This is a descriptive qualitative research that aims to find out about the procedure and internal control at PT. OSI Electronics Batam. This research using purposive sampling and the total of informant is 10 speakers. The data collection technique used is interview, documentation and observation. The results obtained from this study is that implementation of the Internal Control Acceptance Procedure and Expending of Goods in PT. OSI Electronics Batam have been satisfy because has implement indicators of the five aspects of internal control, but the problems appear because of the rolling job in a short time, insufficient security in acceptance of goods, lack of communication between members, and double job for members.
\end{abstract}

Keyword :Internal Control, Acceptance Procedures of goods, Expending Procedures of Goods

\section{PENDAHULUAN}

Penerimaan dan pengeluaran persediaan pada perusahaan merupakan tempat dimana proses awal dalam menjalankan kegiatan perusahaan, dalam proses ini perusahaan harus memiliki prosedur dalam pengelolaannya. Prosedur dalam persediaan adalah hal yang harus dipahami dan dijalankan dengan baik, dengan adanya prosedur maka kinerja karyawan akan lebih teratur dan sesuai dengan tujuan perusahaan. Untuk memastikan apakah prosedur dijalankan dengan baik, maka suatu perusahaan membutuhkan pengendalian internal yang baik, jika pelaksanaan pengendalian internal pada perusahaan sesuai dengan prosedur yang dibuat oleh manajemen, maka akan meminimalisir terjadinya kecurangan atau kesalahan yang mengakibatkan kerugian dalam jangka waktu pendek maupun dalam jangka waktu panjang 
terhadap perusahaan.Dalam proses pengeluaran persediaan muncul beberapa masalah yang dapat ditelaah melalui stock card, beberapa masalah ini muncul karna dalam proses penerimaan maupun pengeluaran persediaan kurang dilakukannya pengendalian internal. Permasalahan pertama, ditemukan permasalahan bahwa pihak receiving kurang teliti dalam menginput quantity, jenis barang, dan salah menempel label pada barangsesuai dengan yang tercantum di surat jalan, Permasalahan kedua, terjadinya kesalahan pencatatan dokumen pada penerimaan persediaan, jumlah barang yang dikirim tidak sesuai dengan yang tertera di surat jalan,aktual barang bisa lebih dan bisa kurang tetapi terlewat oleh pihak receiving dan terjadi kesalahan dalam menghitung jumlah barang. Ada beberapa kasus yang tidak memungkinkan untuk storeman menghitung secara keseluruhan barang yang diterima dan hanya mengecek jumlah barang pada label kemasan luar dengan menyesuaikannya di surat jalan, beberapa hal diantaranya adalah barang kecil yang tak bisa dihitung secara manual dan beberapa barang sensitif yang tidak bisa dibuka kemasannya. Permasalahan ketiga adalah, ditemukan permasalahan yang muncul karena permasalahan kedua yaiu, saat produksi memberi daftar permintaan barang kepada store, ada beberapa barang yang tidak ada di lokasi tetapi ada pada sistem (lost part), dan aktual barang tidak sesuai dengan sistem (No tally).

Berdasarkan latar belakang dan batasan masalah diatas, penulis dapat merumuskan masalah yang muncul pada latar belakang untuk menganalisis permasalahan yang ada, adapun rumusan masalah yaitu, bagaimana pelaksanaan pengendalian internal prosedur penerimaan dan pengeluaran persediaan yang diterapkan oleh PT.OSI Electronics Batam?

Berdasarkan dari rumusan masalah maka penelitian ini bertujuan untuk menganalisis dan memahami bagaimana pelaksanaan pengendalian internal prosedur penerimaan dan pengeluaran persediaan di PT. OSI Electronics Batam.

\section{TELAAH PUSTAKA}

1. Pengertian Pengendalian Internal Menurut Warren, dkk (2017), pengendalian internal merupakan kerangka kerja terintegrasi adalah standar yang digunakan perusahaan dalam mendesain, menganalisis, dan mengevaluasi pengendalian internal. Pengendalian secara luas diartikan sebagai prosedur-prosedur serta proses-proses yang digunakan oleh perusahaan 
untuk melindungi aset perusahaan, mengolah informasi secara akurat, serta memastikan kepatuhan pada hukum dan peraturan yang berlaku.

2. Tujuan Pengendalian internal Menurut Warren, dkk (2017), tujuan pengendalian internal adalah menyediakan keyakinan yang memadai bahwa aset telah dilindungi dan digunakan untuk keperluan bisnis, informasi bisnis akurat, dan karyawan serta manajer mematuhi hokum dan peraturan yang berlaku. Pengendalian internal dapat melindungi aset perusahaan dari pencurian, kecurangan, penyalahgunaan, kesalahan penempatan.

\section{Elemen-elemen Pengendalian Internal.}

Menurut Warren (2017), ada lima unsur pengendalian internal yaitu:

\section{1) Lingkungan Pengendalian}

Lingkungan pengendalian adalah sikap keseluruhan manajemen dan karyawan tentang pentingnya pengendalian. Tiga faktor yang mempengaruhi lingkungan pengendalian perusahaan adalah filosofi manajemen dan gaya operasi, struktur organisasi perusahaan, dan kebijakan personalia perusahaan.

\section{2) Penilaian Risiko}

Semua perusahaan menghadapi risiko seperti perubahan permintaan pelanggan, ancaman pesaing, perubahan peraturan, perubahan dalam faktor-faktor ekonomi.Manajemen harus menilai risiko-risiko tersebut dan melakukan tindakan-tindakan yang diperlukan untuk mengendalikannya.

\section{3) Prosedur Pengendalian}

Prosedur pengendalian dibuat untuk memberikan keyakinan yang memadai bahwa tujuan perusahaan dapat dicapai, termasuk mencegah kecurangan. Prosedur pengendalian meliputi hal berikut ini:

a. Personel yang kompeten, rotasi kerja dan cuti wajib.

b. Pemisahan tanggung jawab untuk operasi yang berkaitan.

c. Pemisahan operasional, penyimpanan aset, dan akuntansi.

d. Bukti dan langkah-langkah keamanan. 


\section{4) Informasi dan Komunikasi}

Informasi dan komunikasi merupakan unsur penting dalam pengendalian internal.Informasi mengenai lingkungan pengendalian, penilaian risiko, prosedur pengendalian serta pengawasan dibutuhkan manajemen untuk mengarahkan operasi dan memastikan kepatuhan pada pelaporan, hukum, dan peraturan yang diperlukan.

\section{5) Pengawasan}

Pengawasan terhadap pengendalian internal dapat menemukan kelemahan-kelemahan dan memperbaiki efektivitas pengendalian. Upaya pengendalian yang berkelanjutan termasuk memantau perilaku karyawan dan sinyal peringatan dari sistem akuntansi

\section{Prosedur Penerimaan dan Pengeluaran Persediaan.}

\section{1) Pengertian Prosedur}

Menurut Mulyadi (2016:4), prosedur adalah suatu urutan kegiatan klerikal, biasanya melibatkan beberapa orang dalam suatu departemen atau lebih yang dibuat untuk menjamin penanganan secara seragam transaksi perusahaan yang terjadi berulang-ulang. Didalam suatu sistem, biasanya terdiri dari beberapa prosedur dimana prosedur-prosedur itu saling terkait dan saling mempengaruhi. Akibatnya jika terjadi perubahan salah satu prosedur, maka akan mempengaruhi prosedur yang lainnya.

\section{2) Pengertian Persediaan}

Menurut Handoko (2016), persediaan adalah suatu istilah umum yang menunjukkan segala sesuatu atau sumber daya-sumber daya organisasi yang disimpan dalam antisipasinya terhadap pemenuhan permintaan. Artinya, persediaan merupakan tempat yang digunakan untuk menyimpan dan memenuhi kebutuhan operasional perusahaan.

\section{3) Prosedur penerimaan dan pengeluaran menurut Irianti (2012):}

\section{a. Prosedur Penerimaan}

Bagian penerimaan barang bertugas untuk menerima semua barang yang dibeli oleh perusahan. Pada saat menerima barang pesanan, bagian ini melakukan perhitungan fisik baik itu menghitung, menimbang atau dengan cara-cara yang lain apakah sudah sesuai dengan order pembelian, di samping itu bagian penerimaan juga harus mengadakan pemeriksaan 
kualitas barang yang diterima. Surat pengangkutan atau pengiriman barang dari pihak pengangkut ditandatangani oleh bagian penerimaan barang.

b. Prosedur Pengeluaran

Barang yang telah di terima dari receiving kemudian disimpan di gudang, lalu mengeluarkan barang sesuai yang dibutuhkan oleh produksi dengan menggunakan list data barang beserta jumlah dari barang yang dibutuhkan.Pengeluaran barang dari gudang dilaksanakan sesuai permintaan yang tercantum di dalam list produksi, list ini merupakan bukti pendukung pengeluaran suatu barang. Pada kartu barang akan tercatat sejumlah pengeluaran sesuai dengan list tersebut. Untuk setiap barang-barang yang dikeluarkan akan diberikan bukti pengantar barang keluar, yang nantinya harus ditandatangani oleh penerima barang. Bukti pengantar keluar salinan yang berupa list yang telah ditanda tangani oleh penerima akan diberi dan yang asli akan diarsipkan.

Berdasarkan teori yang dibahas didalam telaah pustaka, maka dapat digambarkan kerangka pemikiran, yaitu:

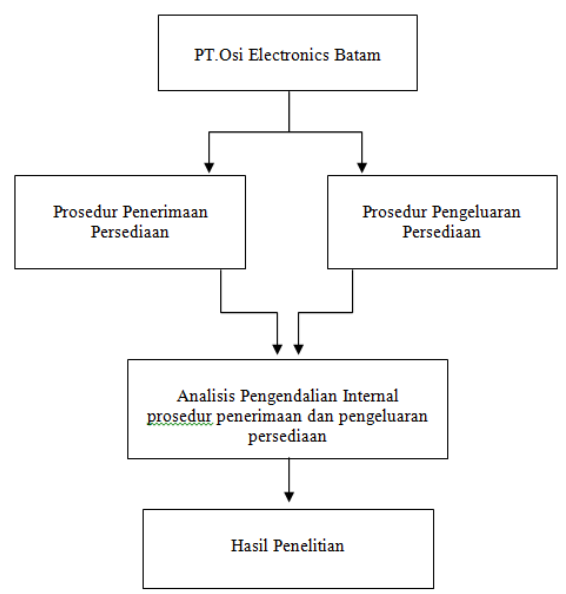

Gambar 1. Kerangka Pemikiran

\section{METODE PENELITIAN}

Jenis penelitian ini adalah kualitatif, didalam penelitian kualitatif tidak menggunakan populasi, karena penelitian kualitatif berangkat dari kasus tertentu yang ada hasil kajiannya tidak akan diberlakukan ke populasi, tetapi ditransferkan ketempat lain pada situasi sosial pada kasus yang dipelajari. Teknik pengambilan sampel yang akan peneliti gunakan adalah 
Purposive sample yaitu pengambilan sampel di mana sumber datanya didasarkan dengan pertimbangan tertentu(Sugiyono, 2017). Sampel yang penulis gunakan adalah dengan cara mewawancarai informan yang sudah ditentukan.

Tabel 1. Informan Wawancara

\begin{tabular}{|c|c|}
\hline No & Jabatan \\
\hline Informan 1 & Manajer \\
\hline Informan 2 & Supervisor \\
\hline Informan 3 & Supervisor \\
\hline Informan 4 & Clerk \\
\hline Informan 5 & Clerk \\
\hline Informan 6 & Leader \\
\hline Informan 7 & Storeman \\
\hline Informan 8 & Storeman \\
\hline Informan 9 & Storeman \\
\hline Informan 10 & Storeman \\
\hline
\end{tabular}

\section{Jenis data}

1. Data Primer, data yang didapat secara langsung antara lain dengan melakukan wawancara ke pihak yang bersangkutan.

2. Data Sekunder, data yang didapat secara tidak langsung yaitu dengan mengumpulkan dokumen-dokumen yang berkaitan seperti struktur organisasi, flowchart, SOP, bukti penerimaan, dan pengeluaran barang.

\section{Teknik Pengumpulan Data}

1. Wawancara, teknik wawancara dilakukan dengan menyiapkan beberapa daftar pertanyaan untuk diajukan kepada calon informan.

2. Observasi, observasi merupakan teknik pengumpulan data dengan melakukan pengamatan langsung kepada objek yang diteliti.

3. Dokumentasi, dokumen merupakan catatan peristiwa yang sudah berlalu.

\section{Teknik analisis data}

Teknik analisis data dalam penelitian ini adalah dengan menggunakan metode perbandingan tetap atau constant comparative method, yaitu metode secara tetap membandingkan satu data dengan data yang lainnya. 
Tahapan-tahapan yang dilakukan adalah sebagai berikut:

1. Mengumpulkan data

2. Mengklarifikasi data

3. Pengeditan

4. Penyajian data

Kemudian hasil dari tahapan-tahapan diatas, dapat ditarik analisa dan kesimpulan.Kesimpulan tersebut dihasilkan dari hasil perbandingan antara implementasi pengendalian internal prosedur penerimaan dan pengeluaran persediaan dengan teori yang ada, lalu mewawancarai informan yang sudah ditentukan dan terkait dengan penelitian sesuai dengan kapasitasnya.Hasil tersebut maka dipersepsikan implementasi pengendalian internalnya yaitu, memadai atau tidak memadai.

\section{HASIL PENELITIAN}

\section{A. Prosedur Penerimaa Persediaan.}

\section{Agility Vendor}

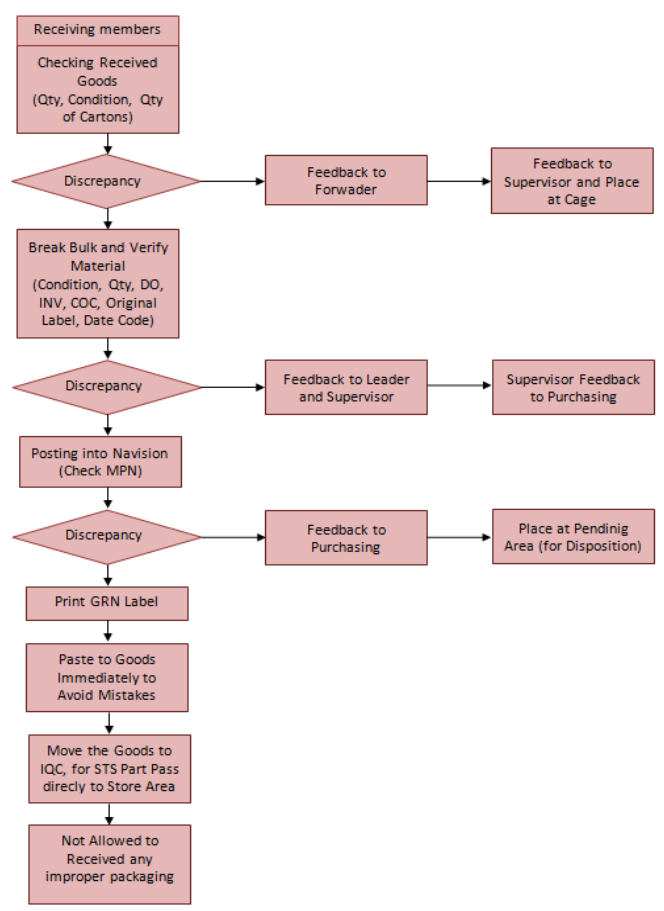

Gambar 2. FlowchartPenerimaan Persediaan (Sumber PT.OSI Electronics) 
Berdasarkan gambar diatas, dapat dijelaskan bahwa:

1) Memeriksa tanda terima kargo terhadap manifes atau pengirim barang (jumlah palet, kondisi kargo, dan jumlah karton).

2) Setiap ada ketidaksesuaian, bagian receiving harus menginformasikan dan mendapatkan konfirmasi kepada pengirim barang untuk memeriksa ulang. Setiap ditemukan barang mencurigakan, tempatkan barang tersebut ditempat yang disediakan khusus dan mengkonfirmasi kepada manager logistic untuk tindakan lebih lanjut.

3) Membongkar palet dan memeriksa barang yang telah diterima terhadap dokumen yang yang terlampir (DOdan invoice) untuk memastikan bahwa part number dan jumlah sesuai dengan dokumen, dan memeriksa kondisi barang, di samping itu, periksa manufacturing date code atau tanggal kadaluarsa (menuliskan tanggal yang diperiksa di dokumen untuk referensi posting), dan memeriksa ketersediaan COC (Certificate of comformance) dari barang tersebut. Selama memeriksa barang-barang yang dikategorikan barang MSD andESD dilarang membuka kemasan atau menyentuh secara langsung dan memindahkan barang tersebut ke tempat khusus memposting barang MSD dan ESD.

4) Jika ditemukan ketidaksesuaian saat melaksanakan poin diatas, konfirmasi kepada purchasing, purchasing akan menghubungi pemasok dan akan menghubungi pihak receiving untuk tidakan selanjutnya. Untuk kasus ketidaksediaan COC, purchasing dan program akan mengajukan DRN, tetapi untuk barang yang dibeli langsung oleh customer tidak diperlukan COC.

5) Memproses penerimaan PO (purchase order) dalam sistem Navision. Pastikan untuk memindai barcode MPN (manufacturing part number) di kemasan barang agar sesuai yang tercantum dengan sistem, jika ada masalah atau ketidaksesuaian konfirmasikan kepada purchasing.

6) Tempatkan barang pending di pending area sambil menunggu keputusan.

7) cetak labal GRN (goods receipt note) menggunakan warna label setiap bulan yang sudah ditentukan, pada label akan menunjukkan otomatis tanggal posting dan tanggal kadaluarsa. 
8) Tempel label ke barang secepatnya untuk menghindari kesalahan atau kesalahan menempel.

9) Pindahkan barang yang telah di GRN dan yang sudah memiliki label ke after GRN area yang telah disediakan atau langsung ke IQC area untuk pengecekan. Untuk barang dengan label tanda STS(ship to stock) pisahkan ke STS area dan langsung masukkan ke racking area store.

10) Pihak receiving tidak boleh menerima barang dengan kemasan tidak benar dari pemasok, yang mungkin menyebabkan potensi risiko pada barang seperti kemasan besar dan kecil didalamnya tanpa bubble bag sebagai pelindung dan pengemasan yang terlalu ketat pada barang yang melebihi kemasan dan akan merusak bagian atas.

\section{Lokal Vendor}

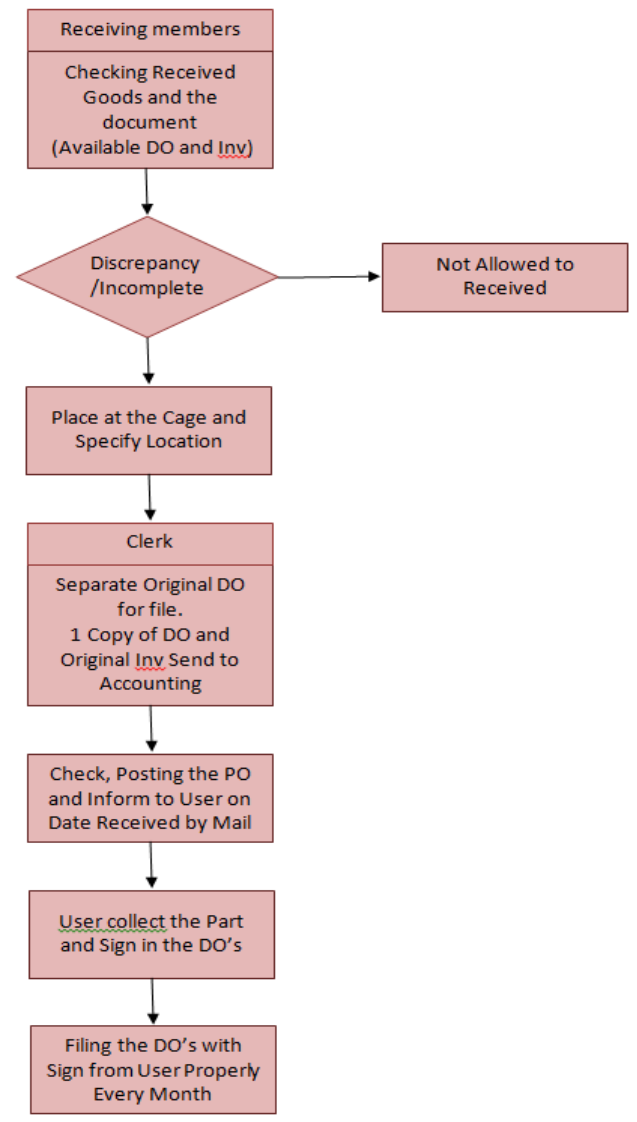

Gambar 3.Flowchart

Proses Penerimaan Persediaan (Sumber PT.OSI Electronics) 
DIMENSI, VOL. 8 , NO. $1: 116-126$

MARET 2019

ISSN: 2085-9996

Berdasarkan gambar diatas, dapat dijelaskan bahwa:

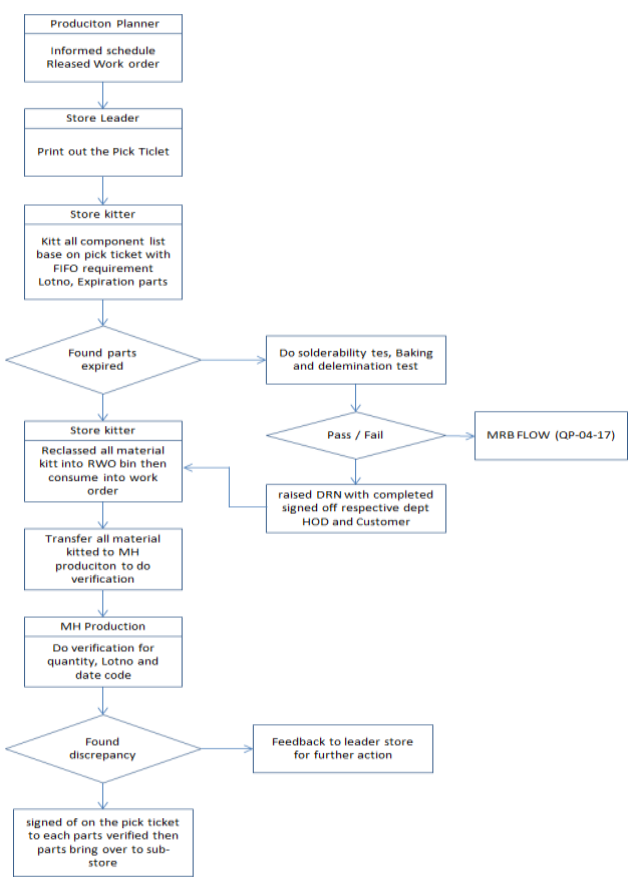

1) Memeriksa aktual barang dan jumlah sesuai dengan dokumen, tanda tangan dan stempel DO dan Invoice, pastikan menerima 2 salin dari dokumen untuk seanjutnya diberikan kepada pihak accounting. Jika ditemukan ketidaksesuaian tidak dibenarkan untuk menerima.

2) Tidak dibenarkan menerima barang tanpa dilengkapi DO dan invoice, segera informasikan ke purchasing bahwa barang telah ditolak. Dalam keadaan urgent pihak purchasing akan menginformasikan ke pihak receiving terlebih dahulu bahwa barang tersebut sangat dibutuhkan, dan memastikan untuk mengirim dokumen secepatnya.

3) Letakkan barang didalam tempat yang telah disediakan dengan mencantumkan nomor lokasi pada DO agar tidak salah memberi barang kepada user.

4) Clerk receiving akan memisahkan 1 lembar salinan DO untuk disimpan, lembar DO dan invoice yang asli untuk selanjutnya diserahkan ke bagian accounting. Pastikan dokumen sudah ditandatangani dan distempel sesuai dengan tanggal penerimaan. Posting PO dengan memperhatikan barang, jumlah, UOM (Unit Of Measure) yang tertera di DO sesuai dengan yang tercantum di sistem. 
5) informasikan melalui email kepada user dalam jangka waktu 24 jam setelah barang diterima untuk mengambil barang tersebut.

6) User akan mengambil barang dan mentandatangani dokumen sebagai bukti bahwa barang telah diterima.

7) Dokumentasikan DO yang sudah ditanda-tangani setiap bulan.

\section{B. Pengendalian Internal Prosedur Pengeluaran Persediaan.}

\section{Gambar 4. Flowchart Proses Pengeluaran Persediaan (Sumber PT.OSI Electronics)}

Berdasarkan gambar diatas, dapat dijelaskan bahwa:

1) Planner menginformasikan RWO untuk dan schedule melalui email.

2) Leader mencetak pick ticket untuk work order yang telah diinformasikan oleh planner melalui email untuk digunakan besok di produksi.

3) Pick ticket (Kitting List) yang sudah dicetak kemudian dibagikan ke storeman untuk dilakukan pengkittingan.

4) Temukan masing-masing material di lokasi yang tertera di pick ticket.

5) Dalam pengambilan material di rak, pastikan langkah-langkah berikut ini:

1. Part number pada material sama dengan part number di pick ticket.

2. Pilihlah lot number yang paling tua.

6) Ambil jumlah sesuai dengan permintaan pada pick ticket. Jika ditemukan jumlah standar untuk SMT material seperti Resistor, Capacitor, Diode, ambil sesuai dengan jumlah standar yang mendekati jumlah di pick ticket. Contoh:

Jumlah yang diminta di pick ticket $\quad: 1.600$

Jumlah standar : 500

Jika diambil 3x500=1.500, ternyata masih kurang 100 dari 1.600

Ambil 4x500=2000, lalu tulis di pick ticket kelebihan 400 atau +400 .

7) Material yang menggunakan kemasan MSD (Moisture Sensitive Device) seperti IC atau LED, harus dikittingkan dalam bentuk jumlah standar.

8) Jika barang sudah diambil di rak sesuai dengan permintaan pada pick ticket, storeman harus memastikan sisa material di rak sesuai dengan yang di sistem. 
9) Setelah itu storeman harus memperbarui stock card dari masing-masing barang yang diambil.

10) Jika ada ketidaksesuaian atau selisih jumlah dan masalah pada material ketika proses pengambilan barang, storeman wajib lapor kepada leader secepatnya agar bisa dilakukan tindak lanjut.

11) Storeman memperbarui di pick ticket sesuai dengan part number, jumlah, lot number, kekurangan atau kelebihan pemberian jumlah dari yang tertera di pick ticket.

12) Untuk barang yang masih ada sisa atau kelebihan di lokasi produksi dan masih mencukupi untuk permintaan work order tersebut, storeman tidak perlu memberi barang lagi secara fisik dari store atau hanya memberi jumlah kekurangan dari jumlah barang di produksi.

13) Jika menemukan barang yang sudah kadaluarsa, storeman harus memisahkan material tersebut dan tidak boleh diberikan kepada produksi, barang tersebut harus dilakukan solderability test terlebih dahulu, jika hasilnya baik maka barang bisa diberikan kepada prosuksi, tetapi sebelum itu harus terlebih dahulu dibuat DRN(Deviation Receipt Note) untuk mendapatkan persetujuan dari customer, kemudian diperpanjang masa kadaluarsanya lebih lama setahun kedepan. Jika hasilnya tidak baik (Reject) harus segera konfirmasi kepada leader untuk selanjutnya dilakukan scrap material kadaluarsa.

14) Storeman akan men-consume (proses transaksi suatu barang kedalam RWO sehingga mengurangi jumlah stok yang ada didalam sistem persediaan produksi) untuk barang yang masih ada sisa di lokasi produksi pada work order sebelumnya.

15) Setelah selesai dikitting, clerk akan melakukan input di sistem untuk mengurangi dan memperbarui stok di sistem.

16) Jika semua proses selesai, barang akan diserahkan ke produksi melalui material handler telebih dahulu untuk dilakukan pemeriksaan terhadap part number, jumlah, lot number dan date code.

\section{PEMBAHASAN}

Dari hasil wawancara dan indikator-indikator didalam aspek-aspek yang termuat dalam kajian teori oleh penelitian terdahulu, divisi PT.OSI hampir memiliki pelaksanaan semua aspek tersebut dengan baik. Disini penulis akan membedah aspek-aspek tersebut lebih lanjut. 


\section{Lingkungan Pengendalian}

\section{1) Integritas dan Nilai Etika}

karyawan selalu menerapkan kesopanan kepada atasan karena menyadari penting dan keharusan melakukannya, menjaga hubungan kerja yang baik terhadap sesama anggota agar selalu kompak dalam bekerja. Hal ini menunjukkan storeman telah memiliki integritas dan nilai etika yang baik, dengan dimilikinya integritas dan nilai etika yang positif didalam ruang lingkup divisi logistik maka akan menimbulkan lingkungan kerja yang nyaman, dengan begitu karyawan akan menikmati setiap pekerjaan dan tidak memiliki internal problem terhadap atasan maupun sesama anggota kerja.

2) Komitmen Terhadap Kompetensi Karyawan telah memiliki komitmen yang sangat tinggi dalam bekerja sesuai dengan yang seharusnya dilakukan dan bekerja sesuai dengan prosedur, mengikuti semua arahan dari atasan dan mentaati yang diperintahkan, dengan begitu maka kinerja karyawan akan menghasilkan output yang baik, tidak ada unsur-unsur kesengajaan melakukan kesalahan ataupun mood swing dalam bekerja.

3) Dewan Direksi dan Komite AuditPartisipasi oleh dewan direksi yang penulis dapat sangat aktif dalam pengelolaan di masing-masing divisi, hal ini dapat dilihat dari pernyataan manajer bahwa dalam setahun direktur OSI akan mengunjungi setiap divisi-divisi, direktur akan melihat langsung pengelolaan terhadap kinerja, keadaan divisi tersebut, dan melakukan internal audit terhadap dokumen dan aktual pelaksanaan prosedur. Hal ini sangat berpengaruh dalam kegiatan operasional, dengan adanya partisipasi dari dewan direksi, maka manajer akan selalu memastikan pengendalian internal prosedur yang dibuat, dan akan semakin termotivasi untuk memperbaiki divisi logistik menjadi lebih baik lagi dengan perencanaan-perencanaan meminimalisir kesalahan dan risiko yang mungkin terjadi.

\section{4) Gaya Operasi Manajemen}

Manajer telah memiliki gaya-gaya operasi dalam menunjang pengendalian internal demi kelancaran proses penerimaan dan pengeluaran, hal ini dapat dilihat dari manajer yang selalu melakukan perbaikan prosedur setiap terjadinya masalah, manajer melakukan pembaharuan terhadap prosedur setiap munculnya permasalahan dan akan memperketat setiap proses kerja. Inovasi terbaru dalam pengelolaan karyawan seperti job rolling untuk memaksimalkan kinerja, 
meminimalisir kebosanan dan kecurangan terhadap kerja dan sebagai ilmu pengetahuan terhadap job desk lainnya.Hal ini menunjukkan bahwa manajer memiliki gaya operasi manajemen yang baik, karna dengan adanya job rolling atau pemindahan job desk akan memaksimalkan kinerja dan produktivitas karyawan, akan lebih banyak sumber daya yang menguasai ilmu pengetahuan terhadap semua job desk dan hal tersebut akan bermanfaat untuk mengefisienkan sumber daya pada divisi logistik.

\section{5) Struktur Organisasi}

Struktur organisasi didalam divisi logistik telah tersusun dengan baik.Karena struktur organisasi yang ada telah terbentuk dan tersusun dengan rapi, dan memiliki masing-masing job desk untuk setiap karyawan.

\section{6) Penetapan Wewenang dan Tanggung Jawab}

Pada saat interviewsudah dipilih karyawan yang berkompeten dibidangnya dan telah ditetapkan wewenang terhadap job desk yang diberikan.Clerk memiliki tanggung jawab yang tinggi terhadap wewenang yang telah diberi untuk menyelesaikan masalah didalam pekerjaannya.Hal ini menunjukkan penetapan wewenang terhadap job desk sudah disusun dengan baik dan sudah diterapkannya tanggung jawab yang tinggi terhadap wewenang yang diberi.

\section{7) Kebijakan dan Praktik}

Kebijakan yang mendukung praktik kerja pada karyawan sudah terbentuk dalam proses penerimaan dan pengeluaran persediaan yaitu prosedur penerimaan dan pengeluaran persediaan dan praktik yang dilakukan terhadap prosedur sudah dilaksanakan dengan baik. Dengan adanya praktik yang baik oleh karyawan terhadap prosedur yang ada maka akan meminimalisir adanya kesalahan dalam bekerja dan mencegah suatu masalah timbul setiap harinya yang akan berdampak pada jangwa waktu yang panjang.

\section{Penilaian Risiko}

\section{1) Keterlibatan Manajer}

Manajer memiliki perencanaan khusus terhadap risiko yang mungkin terjadi yaitu pengelolaan pembuangan sampah, melakukan cycle count setiap harinya, dan mengontrol karyawan yang bukan bagian dari logistik memasuki area, dan melakukan konsep 6S. Hal ini menunjukkan 
bahwa manajer terlibat dalam penilaian risiko terhadap kehilangan barang yang mungkin terjadi, kesalahan yang tidak sengaja ketika membuang sampah box, cycle count yang dilaksanakan setiap hari untuk mengetahui status suatu barang, jika ditemukan variance maka akan segera dilakukan negative out dari sistem, hal ini akan mencegah kehilangan barang ketika barang tersebut dibutuhkan dan agar bisa dilakukan pembelian kembali untuk menyuplai stok yang kurang. Memberlakukan setiap karyawan eksternal divisi logistik harus memiliki visitor card sebelum memasuki area tertentu sangat dibutuhkan pada divisi logistik, tetapi akan lebih baik jika divisi logistik mengontrol agar tidak terlalu banyak karyawan yang keluar masuk area store, hanya perwakilan dari divisi masing-masing yang diperbolehkan masuk dengan kepentingan tertentu

\section{2) Penindaklanjutan Risiko}

Penindaklanjutan risiko dilakukan dengan aktif oleh atasan dilihat dari tindakan-tindakan yang dapat meminimalisir risiko dalam ruang lingkup area kerja dan memastikan untuk selalu safety, atasan juga selalu mengelola dan bertindak segera setiap masalah yang timbul dari risiko yang mungkin terjadi ketika ditemukan barang yang tidak dapat ditemukan, penyebabpenyebab tidak ditemukannya barang adalah salah peletakan barang yang tidak sesuai dengan lokasi pada sistem, kelebihan memberi barang pada saat menghitung, dan salahnya pemberian barang dikarenakan kemiripan part number diantara dua barang. Supervisor akan terlebih dahulu memeriksa history barang tersebut lewat sistem dan akan menginstruksikan semua karyawan store untuk menyisir setiap rak dan mencari bersama, jika tidak dapat ditemukan juga maka supervisor akan menghubungi buyer dan planner untuk menghilangkan (negative out) dari sistem agar buyer bisa menyuplai barang tersebut lebih cepat dan planner bisa menunda jalannya proses produksi yang membutuhkan barang tersebut. Jika supervisor menemukan storeman atau anggota yang mengakibatkan barang tersebut hilang maka akan dikenakan sanksi yang berlaku. Hal ini menunjukkan supervisor telah melaksanakan wewenangnya atas penindklanjutan risiko dengan maksimal dan kegigihan untuk mengatasi risiko yang terjadi sebelum dilakukannya negative out yang akan berdampak buruk terhadap reputasi kinerja karyawan divisi logistik. 
DIMENSI, VOL. 8, NO. $1: 116-126$

MARET 2019

ISSN: 2085-9996

\section{Aktivitas Pengendalian}

\section{1) Otoritas Transaksi}

Pihak receiving dan store sudah mengetahui dan melaksanakan otoritas terhadap barang sesuai dengan prosedur yang dibuat, hal ini dapat dilihat karena setiap karyawan telah mendapat training terlebih dahulu, dan melaksanakannya dengan baik, akan tetapi terdapat kelemahan dalam otoritas penerimaan barang dari supplier karna proses penerimaan seperti menghitung barang, memeriksa barang, kelengkapan dokumen, sign dan stamp pada dokumen-dokumen tidak dilakukan oleh anggota tertentu, melainkan semua anggota receiving memiliki wewenang dalam proses penerimaan.

\section{2) Pemisahan Tugas}

Pemisahan tugas sudah tertulis dengan jelas pada job desk, tetapi pada aktualnya tidak dilakukan dengan baik kepada karyawan karna tidak jelasnya antara job desk masing-masing karyawan, hal ini dapat dilihat dari clerk receiving membantu pekerjaan dari clerk store karna banyaknya pekerjaan dengan anggota yang minim pada pihak store, pekerjaan sebelumnya akan terbengkalai atau tertunda karena adanya pemindahan dalam waktu singkat dan ada kemungkinan akan terlupa karena terbaginya fokus kerja pada clerk, dampak dari tertundanya job desk sebelumnya akan muncul dalam beberapa hari kedepan dan akan membuat pekerjaan clerk menumpuk. Job rolling yang diterapkan oleh manajer tidak bersifat permanen dan memiliki jangka waktu yang pendek, ketika karyawan mulai memfokuskan dan memahami job desk, dengan pendeknya jangka waktu dari job rolling yang diberi maka karyawan akan kehilangan fokus terhadap job desk yang lama dan akan memaksa diri untuk cepat memahami dan beradaptasi dengan pekerjaan dan lingkungannya. Job rolling yang diberlakukan oleh manajer sangat efektif dalam kecepatan dan efisien waktu terhadap sumber daya divisi logistik, tetapi jika jangka waktu pemindahan atau job rolling dilakukan singkat dalam satu atau dua hari dan disaat dibutuhkan saja, maka akan menimbulkan masalah untuk waktu yang akan datang, contohnya waktu yang digunakan dalam mem-posting barang masuk dari supplier sangat cepat ketika adanya pemindahan storeman store untuk membantu storeman receiving ketika penerimaan barang sangat banyak pada hari tersebut, tetapi masalah akan muncul seminggu kemudian seperti salahnya penempelan label pada part number dan akan 
ditemukan oleh IQCsaat pengecekan karena tidak ada ketidaksesuain antara label dan sistem, jumlah yang di-posting tidak sesuai dengan jumlah yang tertera pada original label dari supplier, masalah ini ditemukan ketika barang akan dilakukan pemindahan barang ke rak store.

\section{3) Penggunaan Dokumen}

Penggunaan dokumen sudah sesuai dengan kebutuhannya sebagai referensi untuk penginputan data dan telah teliti dalam proses penginputan. Beberapa karyawan yang melakukan proses pemeriksaan dokumen yang baik dan sesuai dengan prosedur. Hal ini dapat dilihat dari kesadaran akan pentingnya dokumen pada proses pekerjaannya untuk memeriksa lebih detail dan memininalisir terjadinya miss out pada dokumen dan ketidaksesuaian antara yang tertulis pada dokumen dengan fisik barang yang diberi.Tetapi ada dari clerk yang tidak melakukan pemeriksaan terhadap dokumen dengan baik karena beberapa alasan tertentu, hal ini didapat dari pengakuan karyawan tersebut yang mengaku tidak memiliki cukup waktu dalam pemeriksaan dokumen lebih lanjut karena banyaknya kerjaan yang didapat dan melakukan pekerjaan dliluar dari job desk yang diberikan. Hal ini menunjukkan bahwa job rolling atau pemindahan merupakan faktor dari alasan clerk tidak melakukan pemeriksaan lebih lanjut terhadap dokumen, walaupun dengan alasan tersebut bisa dimaklumi seharusnya clerk tetap menjaga proses pemeriksaan dokumen tetap dilakukan dengan teliti dan tidak melewatinya, dokumen-dokumen yang tidak diperiksa ini akan menjadi acuan saat timbulnya masalah seperti salahnya penulisan jumlah pada aktual yang diberi oleh storeman dan kesesuaian barang pada dokumen dan fisiknya saat penerimaan barang, dokumen merupakan bagian yang harus tetap diperhatikan karena merupakan bentuk pengendalian internal dalam pelaksanaannya.

4) Pemeriksaan Independen KerjaPelaksanaan dan pemeriksaan terhadap kinerja dari karyawan sudah dilakukan dengan teliti, hal ini dapat dilihat dari karyawan yang melakukan crosscheck untuk menghindari adanya short dan extra pada barang dengan menggunakan visual check dan system check terhadap pekerjaannya dan selalu melaporkan segera ketika ditemukannya kendala seperti seperti No COC, Short, Extra, No Original label pada proses penerimaan barang di receiving dan actual received dan system Navision tidak sama ataupun 
barang-barang yang kadaluarsa di rak pada proses pengeluaran barang di store.Tetapi ke-4 storeman bekerja dengan tergesa-gesa didalam penyelesaian tugas, hal ini dikarenakan oleh alasan dari output yang harus didapat oleh storemansetiap harinya sangat tinggi dan tidak memungkinkan storeman untuk bekerja dengan kecepatan konsisten. Hal ini sangat berdampak buruk untuk masa yang akan datang, dengan output yang sudah ditentukan oleh atasan akan mengefisienkan waktu bekerja dari karyawan, tetapi setiap karyawan memiliki kemampuan yang berbeda-beda dan jika karyawan melakukan pekerjaan dengan tergesa-gesa, maka akan membuat karyawan kurang memperhatikan hal-hal yang perlu diperiksa lebih teliti.

\section{Sistem Informasi dan Komunikasi}

\section{1) Sistem Informasi}

Divisi logistik telah memiliki sistem yaitu sistem Navision untuk mengetahui status dari tiaptiap barang yang masuk dan keluar.

\section{2) Informasi dan Komunikasi}

Proses informasi dan komunikasi yang diterapkan oleh divisi logistik sudah memadai dan diterapkan dengan baik, hal ini dapat dilihat bahwa adanya kesadaran dari karyawan pentingnya menjaga komunikasi antar sesama anggota dan divisi lain seperti accounting purchasing, program, planner, IQC, user, dan pihak-pihak lain yang terkait. Contohnya setiap kendala yang muncul didalam proses penerimaan di receiving harus selalu mendapat feedback dari pihak accounting, purchasing, program, IQC, untuk setiap masalah yang terkait. Dan masalah yang muncul didalam proses pengeluaran persediaan harus selalu mendapat feedback dari planner, program, IQC, dan produksi. Untuk informasi sesama divisi juga telah dilakukannya dengan baik, seperti selalu mengkonfirmasi dengan segera kepada leader atau atasan ketika ditemukannya masalah dan tidak menunda barang bermasalah tersebut, dan menyerahkan semua pekerjaan yang tertunda kepada anggota yang menggantikan ketika akan mengajukan cuti.Tetapi masih ditemukan adanya kurang jelas komunikasi terhadap karyawan first shift dan second shift, hal ini dapat dilihat dari karyawan yang mengaku hanya meninggalkan catatan yang kurang jelas akibat tidak bertemu secara langsung dengan anggota second shift untuk melakukan penyerahan tugas yang dilakukannya, dan meninggallan tugas kepada leader yang kemudian akan disampaikan oleh leader tersebut, hal ini akan 
mengakibatkan kurang jelasnya informasi atas komunikasi yang dilakukan dan akan memungkinkan terjadinya kesalahan terhadap tugas yang akan dilanjutkan.

\section{Pengawasan}

\section{1) Keterlibatan Manajer}

Pengawasan terhadap pengelolaan kinerja dan proses pekerjaan telah dilaksanakan oleh atasan, hal ini dapat dilihat dari supervisor dan leader yang aktif dan memantau secara langsung kinerja karyawan, supervisor dan leader memiliki kesadaran atas pentingnya pengawasan karena dengan begitu atasan akan mengetahui dan mengevaluasi kinerja karyawan yang baik dan buruk. Dengan pengawasan atasan akan memantau apakah prosedur telah dijalankan dengan baik dan tidak melenceng dari yang ditugaskan, dengan begitu akan meminimalisir terjadinya penyimpangan dan kesalahan atas kinerja karyawan yang mungkin akan menimbulkan masalah dimasa yang akan datang dan memantau produktivitas karyawan untuk tidak berbincang dan menggunakan handphone. Tetapi disini penulis melihat tidak adanya pengawasan secara langsung dari manajer logistik terhadap kinerja karyawan, hal ini dapat dilihat dari pengakuan manajer bahwa tugas mengawasi dan memantau hanya dilakukan oleh supervisor dan leaderkarena merupakan tugas dari jabatan tersebut dan hanya menerima laporan-laporan atas pengawasan yang dilakukan.

\section{2) Feedback}

Hasil dari pengawasan yang dilakukan oleh supervisor dan leader selalu dilaporkan dengan segera kepada manajer,jika suatu kendala tidak bisa diselesaikan oleh supervisor, maka akan melaporkannya kepada manajer logistik untuk penangananan lebih lanjut. Hal ini dapat dilihat dari pengakuan manajer bahwa akan menyelesaikan masalah sesuai dengan otoritas dan wewenang yang dimilikinya ketika supervisor tidak bisa menyelesaikannya. Dengan adanya feedback yang aktif oleh manajer, maka divisi logistik telah menyadari pentingnya feedback dan risiko dalam jangka waktu panjang jika menunda untuk menyelesaikan laporan masalah yang diterima.

\section{KESIMPULAN}

Didalam hasil dan pembahasan menunjukkan bahwa pelaksanaan pengendalian internal prosedur penerimaan dan pengeluaran sudah memadai karena indikator-indikator 
terhadap kelima aspek telah dijalankan dengan baik, akan tetapi masalah-masalah yang ditimbulkan disebabkan oleh adanya konsep job rolling yang diberlakukan dalam waktu singkat, manajer menerapkan konsep job rolling pada karyawan store dan receiving hanya dalam waktu tertentu ketika dibutuhkannya manpower untuk pekerjaan yang sedang banyak. Terdapat kelemahan security terhadap penerimaan barang karena semua anggota receiving memiliki wewenang untuk menerima barang dari supplier. Kurangnya komunikasi yang baik antar anggota first shift dan second shiftsaat penyerahan pekerjaan. Terjadinya double job pada clerk yang membuat kurangnya pemeriksaan terhadap kesesuaian jumlah yang tertera pada barang dengan dokumen yang terlampir.

\section{SARAN}

1. Sebaiknya manajer menentukan jangka waktu yang tetap dalam pelaksanaan job rolling dan pemindahan karyawan, contohnya rolling dan pemindahan dilakukan satu kali dalam waktu sebulan.

2. Wewenang untuk mentandatangani dan stamppenerimaan barang dari supplier hanya dilakukan oleh satu atau dua orang dan memperketat penerimaan barang seperti menghitung jumlah, kesesuaian dokumen dan kualitas barang yang masuk.

3. Sebaiknya leader memastikan untuk anggota first shift dan second shift bertemu dan menyerahkan tugas dengan rinci.

4. Sebaiknya target yang ditentukan oleh manajer dilakukan dengan bertahap dan akan menambah target jika kecepatan bekerja karyawan sudah stabil, agar karyawan tidak bekerja dengan terburu-buru yang akan mengakibatkan masalah di masa mendatang,

5. Sebaiknyaclerk memiliki beban kerja yang seimbang dan sesuai dengan job desk, supervisor memonitor untuk tidak adanya double job.

6. Sebaiknyamengontrol agar tidak terlalu banyak karyawan yang keluar masuk area store. 


\section{DAFTAR PUSTAKA}

Handoko, T. Hani (2016). Dasar-Dasar Manajemen Produksi dan Operasi.Jakarta: BPFE.

Irawati, Rusda dan Ardhila Kamalita Satri (2017).Analisis Pelaksanaan Sistem Pengendalian Internal pada Prosedur Penerimaan dan Pengeluaran Barang di PT Unisem Batam. Jurnal: Fakultas Administrasi Bisnis Universitas Politeknik Negeri Batam.

Irianti, Ida (2012). Evaluasi Pengendalian internal terhadap prosedur penerimaan dan penataan barang di PT Jatiluhur Agung.Jurnal: Fakultas Ekonomi Universitas Dian Nuswantoro Semarang.

Mulyadi (2016).Sistem Akuntansi. Ed. 4. Jakarta: Salemba Empat.

Sugiyono (2017). Metode Penelitian. Bandung: Alfabeta.

Warren, Carl S., James M. Reeve, dkk (2017). Pengantar Akuntansi 1-Adaptasi Indonesia. Ed.4. Jakarta: Salemba Empat 